51-60

Accepted: June 1, 2018

http://ejournal-kertacendekia.id/index.php/nhjk/

(C) 2018 Nurse and Health: Jurnal Keperawatan

\title{
HUBUNGAN POLA ASUH ORANGTUA DENGAN KEMANDIRIAN PERSONAL HYGIENE ANAK USIA PRASEKOLAH DI TKIT PERMATA MULIA DESA BANJARAGUNG KECAMATAN PURI KABUPATEN MOJOKERTO
}

\author{
Henny Vidya ${ }^{1}$, Surya Mustikasari ${ }^{1}$ \\ ${ }^{1}$ STIKES Dian Husada Mojokerto \\ *Correspondence: \\ Henny Vidya \\ Email: hennyputrapratama@gmail.com
}

\begin{abstract}
Background: Many preschool children are lacking in maintaining their personal hygiene so that this facilitates the occurrence of illness due to lack of maintaining personal hygiene such as worms or diarrhea. This happens because the child is still not able to do personal hygiene independently or still assisted by parents.

Purpose: The purpose of the study was to analyze the relationship of parenting with the independence of personal hygiene of preschoolers. Method: The research design is correlational analytic with crossectional approach. The study population is All parents and preschool children in kindergarten Permata Mulia Banjaragung Mojokerto as much as 41 mother and child. The sample was taken by purposive sampling technique as many as 37 respondents. The research variables are parenting as an independent variable and personal hygiene independence as dependent variable. Data were collected by questionnaire instrument of self-care pattern and self-reliance of hygiene, then chi square test.

Results: The result of the research shows that 15 of the respondents have adopted the democratic parenting of most of the autonomy of children in the self-supporting category as many as 8 respondents $(53.3 \%)$. Of the 9 respondents who apply authoritarian parenting system there is 1 child $(11.1 \%)$ who are independent and parents Applying permissive parenting pattern of most children belonging to self-reliant as many as 7 resondents $(53.8 \%)$. Chi square test results obtained values $\rho=0,023$ and $\alpha=0.05$ so that $\rho<\alpha$ then there is a Relationship Pattern Parenting with Child Independence Level.

Conclusion: There is no best parenting pattern but parents should be able to choose the appropriate parenting pattern in children according to the situation and condition of the child, which is expected later on children have good independence early.
\end{abstract}

Key words: Parenting, Independence, Preschool

\section{PENDAHULUAN}

Masa depan anak dikemudian hari akan sangat tergantung dari pengalaman yang didapatkan anak termasuk faktor pendidikan dan pola asuh orang tua. Di saat sekarang ini tidak sedikit orang tua yang mengejar kepentingan mereka sendiri dengan dalih untuk kesejahteraan anak, sehingga terkadang peran mereka sebagai orang tua yaitu mendidik dan mengasuh anak terlalaikan (Habibi, 2007). Pola asuh orang tua merupakan gambaran tentang sikap dan perilaku orang tua dengan anak dalam berinteraksi, serta berkomunikasi 
selama mengadakan kegiatan pengasuhan. Pola asuh yang tepat akan mempengaruhi tingkat kemandirian anak dalam segala bidang, salah satunya adalah kemandirian dalam personal hygiene anak (Yunanda, 2012). Permasalahan kesehatan pada anak usia prasekolah berkaitan dengan kebersihan perorangan dan lingkungan, seperti gosok gigi yang baik dan benar, kebiasaan cuci tangan memakai sabun, dan kebersihan diri (Judarwanto, 2005). Fenomena yang terjadi saat ini masih banyak anak usia sekolah yang kurang dalam menjaga kebersihan diri mereka sehingga hal ini mempermudah terjadinya penyakit akibat kurang menjaga kebersihan diri seperti cacingan atau diare. Hal ini terjadi karena anak masih belum mampu melakukan personal hygiene secara mandiri atau masih dibantu oleh orang tua.

Hasil pemeriksaan tinja yang dilakukan di delapan provinsi di Indonesia pada tahun 2013 menunjukkan prevalensi kecacingan mempunyai rentang yang cukup lebar, yaitu antara 2,7\% di Sulawesi Utara hingga 60,7\% di Banten, sedangkan di Kalimantan Barat sebesar 26,2\% (Lestari, 2014). Hasil Riskesdas Tahun 2013 insiden atau prevalensi diare pada semua umur dengan jumlah kasus terbanyak adalah provinsi Papua, provinsi NTT, sedangkan kasus diare pada balita terbanyak pada daerah Aceh sebanyak 10,2 $\%$ dari jumlah balita dan pada provinsi jawa timur sebanyak 6,7\% dari jumlah balita. Hasil observasi yang dilakukan peneliti di TKIT Permata Mulia desa Banjaragung Kabupaten Mojokerto terhadap 10 siswa diperoleh data 5 siswa rambutnya tampak kotor, dan kusam, 3 siswa jarang mencuci tangan setelah bermain dan mereka langsung mengambil makanan, 2 siswa kuku tampak jarang dibersihkan dan kotor.
Kemandirian (autonomi) adalah individu memiliki sikap mandiri dalam cara berpikir dan bertindak, mampu mengambil keputusan mengarahkan dan mengembangkan serta menyesuaikan diri sesuai dengan norma yang berlaku dilingkungannya. Faktor yang mempengaruhi pembentukan kemandirian yaitu faktor internal dan faktor eksternal. Faktor internal yaitu faktor emosi dan faktor intelektual, dan faktor eksternal yaitu lingkungan, pola asuh, karakteristik anak, kualitas informasi dan status pekerjaan (Hurlock dalam Yusuf, 2009). Faktor yang mempengaruhi pola asuh orang tua menurut Suparyanto (2012) yaitu sosial ekonomi orang tua, pendidikan, nilai-nilai agama yang dianut orang tua, kepribadian orang tua, dan jumlah anak. Pola asuh orang tua merupakan gambaran tentang sikap dan perilaku orang tua dengan anak dalam berinteraksi, serta berkomunikasi selama mengadakan kegiatan pengasuhan. Kemampuan interpersonal dan pengendalian emosional sangat diperlukan orang tua dalam melakukan kegiatan pengasuhan untuk memberikan rasa nyaman pada anak. Pola asuh yang tepat akan mempengaruhi tingkat kemandirian anak (Santrock, 2007). Anak-anak yang tidak mandiri cenderung tidak percaya diri dan tidak mampu menyelesaikan tugas hidupnya dengan baik. Akibatnya, prestasi belajarnya bisa mengkhawatirkan. Anakanak seperti ini senantiasa bergantung pada orang lain; misalnya mulai dari persiapan berangkat sekolah, mengerjakan pekerjaan rumah, sampai dalam pola belajarnya (Suseno, 2014). Petranto (2006) menerapkan bahwa dampak pola asuh demokratis akan menghasilkan anak yang mandiri dan kooperatif dengan orang lain, pola asuh otoriter akan menghasilkan anak 
yang penakut, pendiam, dan tertutup sedangkan pola asuh permisif akan menghasilkan anak yang tidak patuh, manja dan kurang mandiri.

Upaya yang dapat dilakukan dalam pengembangan kemandirian anak yaitu peran aktif orang tua dalam menciptakan lingkungan rumah sebagai lingkungan osial yang pertama dialami oleh anak, dimana anak secara bertahap mampu melepaskan diri dari ketergantungan serta perlindungan mutlak dari orang tuanya. Kedua orang tua dapat mengembangkan rasa kasih sayang secara seimbang dengan memberi kesempatan anak untuk menunjukkan kasih sayang (Kanisius, 2006). Solusi yang dapat dilakukan peneliti dan ibu guru sebagai health educator dengan pemberian penyuluhan tentang pola asuh orang tua terhadap kemandirian anak usia prasekolah di TKIT Permata Mulia desa Banjaragung Kabupaten Mojokerto. Setelah mendapatkan penyuluhan tentang pola asuh orang tua terhadap kemandirian personal hygiene anak diharpakan pegnetahuan orang tua meningkat dan termotivasi untuk melakukan perubahan poal asuh orang tua terhadap kemandirian anak ditunjang penerapan pola asuh yang tepat, dan orang tua perlu juga membangun kedekatan terhadap anak dengan cara melakukan komunikasi yang logis (Jalaludin, 2003). Selain itu orang tua juga bisa membaca Koran, majalah dan melihat youtube tentang pola asuh yang benar.

\section{METODE DAN BAHAN}

Penelitian ini menggunakan desain analitik korelasional dengan menggunakan pendekatan cross Sectional yaitu jenis penelitian yang menekankan pada waktu pengukuran/observasi data variabel independen dan dependen hanya satu kali, pada satu saat. Tentunya tidak semua subjek penelitian harus diobservasi pada satu hari atau pada waktu yang sama, akan tetapi baik variabel independen maupun variabel dependen dinilai hanya satu kali saja (Nursalam, 2013).

\section{HASIL PENELITIAN}

\section{Karakteristik Responden Berdasarkan Usia Ibu.}

Tabel 1. Karakteristik Responden Berdasarkan Usia Ibu di TKIT Permata Mulia Desa Banjaragung Kecamatan Puri Kabupaten Mojokerto.

\begin{tabular}{|c|c|c|}
\hline Usia Ibu (Tahun) & Frekuensi (f) & Prosentase (\%) \\
\hline $20-35$ & 35 & 94,6 \\
\hline$>35$ & 2 & 5,4 \\
\hline Total & 37 & 100 \\
\hline
\end{tabular}

Berdasarkan tabel 1 dapat menunjukkan bahwa hampir seluruhnya responden berusia 20-35 tahun sebanyak 35 responden $(94,6 \%)$.

\section{Karakteristik Responden Berdasarkan Usia Anak.}

Tabel 2. Karakteristik Responden Berdasarkan Usia Anak di TKIT Permata Mulia Desa Banjaragung Kecamatan Puri Kabupaten Mojokerto.

\begin{tabular}{|c|c|c|}
\hline Umur (tahun) & Frekuensi (f) & Prosentase (\%) \\
\hline 4 & 7 & 18,9 \\
\hline 5 & 20 & 54,1 \\
\hline 6 & 10 & 27 \\
\hline Total & 37 & 100 \\
\hline
\end{tabular}

Berdasarkan hasil penelitian diatas dapat diketahui bahwa sebagian besar responden berusia 5 tahun sebanyak 20 responden $(54,1 \%)$. 
Karakteristik Responden Berdasarkan Pendidikan Ibu.

Berdasarkan tabel 3 dapat menunjukkan bahwa sebagian besar responden mempunyai latar belakang pendidikan SLTA sebanyak 28 responden $(75,7 \%)$.

Tabel 3. Karakteristik Responden Berdasarkan Pendidikan Ibu di TKIT Permata Mulia Desa Banjaragung Kecamatan Puri Kabupaten Mojokerto.

\begin{tabular}{|c|c|c|}
\hline Pendidikan Ibu & Frekuensi (f) & Prosentase (\%) \\
\hline SD & 2 & 5,4 \\
\hline SMP & 5 & 13,5 \\
\hline SMA & 28 & 75,7 \\
\hline PT & 2 & 5,4 \\
\hline Total & 37 & 100 \\
\hline
\end{tabular}

Karakteristik Responden Berdasarkan Usia Kehamilan.

Tabel 4. Karakteristik Responden Berdasarkan Pekerjaan Ibu di TKIT Permata Mulia Desa Banjaragung Kecamatan Puri Kabupaten Mojokerto.

\begin{tabular}{|c|c|c|}
\hline Pekerjaan Ibu & Frekuensi (f) & Prosentase (\%) \\
\hline Tidak Bekerja & 23 & 62,2 \\
\hline Bekerja & 14 & 37,8 \\
\hline Total & 37 & 100 \\
\hline
\end{tabular}

Dari tabel 4 diketahui bahwa sebagian besar responden tidak bekerja atau sebagai ibu rumah tangga sebanyak 23 responden $(62,2 \%)$.

\section{Karakteristik Responden Berdasarkan Pola Asuh Orangtua.}

Tabel 5. Karakteristik Responden Berdasarkan Pola Asuh Orangtua di TKIT Permata Mulia Desa Banjaragung Kecamatan Puri Kabupaten Mojokerto.

\begin{tabular}{|c|c|c|}
\hline Pola Asuh & Frekuensi (f) & Prosentase (\%) \\
\hline Demokratis & 15 & 40,5 \\
\hline Otoriter & 9 & 24,3 \\
\hline Permisif & 13 & 35,1 \\
\hline Total & 37 & 100 \\
\hline
\end{tabular}

Berdasarkan data pada tabel 5 diketahui bahwa hampir setengahnya orang tua responden menerapkan pola asuh demokratis sebanyak 15 responden $(40,5 \%)$.

\section{Karakteristik Responden Berdasarkan Kemandirian Anak.}

Tabel 6. Karakteristik Responden Berdasarkan Kemandirian Anak di TKIT Permata Mulia Desa Banjaragung Kecamatan Puri Kabupaten Mojokerto.

\begin{tabular}{|c|c|c|}
\hline Kemandirian & Frekuensi (f) & Prosentase (\%) \\
\hline Tidak Mandiri & 7 & 18,9 \\
\hline Kurang Mandiri & 14 & 37,8 \\
\hline Mandiri & 16 & 43,2 \\
\hline Total & 37 & 100 \\
\hline
\end{tabular}

Berdasarkan hasil data pada tabel 6 didapatkan bahwa hampir setengahnya anak prasekolah di TKIT Permata Mulia mengalami kemandirian dalam kategori Mandiri sebanyak 16 responden $(43,2 \%)$.

\section{Hubungan Pola Asuh Orangtua dengan Tingkat Kemandirian Anak.}

Tabel 7. Tabulasi Silang Hubungan Pola Asuh Orangtua dengan Tingkat Kemandirian Anak di TKIT Permata Mulia Desa Banjaragung Kecamatan Puri Kabupaten Mojokerto.

\begin{tabular}{|c|c|c|c|c|c|c|c|c|}
\hline Pola Asuh & \multicolumn{9}{|c|}{ Kemandirian } & \multicolumn{2}{|c|}{ Total } \\
\cline { 2 - 10 } & \multicolumn{2}{|c|}{$\begin{array}{c}\text { Kurang } \\
\text { Mandiri }\end{array}$} & \multicolumn{2}{|c|}{ Mandiri } & \multicolumn{2}{c|}{$\begin{array}{c}\text { Tidak } \\
\text { Mandiri }\end{array}$} & \multicolumn{2}{|c|}{} \\
\cline { 2 - 10 } & f & $\%$ & f & $\%$ & f & $\%$ & f & $\%$ \\
\hline Demokratis & 6 & 40 & 8 & 53,3 & 1 & 6,7 & 15 & 100 \\
\hline Otoriter & 3 & 33,3 & 1 & 11,1 & 5 & 55,6 & 9 & 100 \\
\hline Permisif & 5 & 38,5 & 7 & 53,8 & 1 & 7,7 & 13 & 100 \\
\hline Total & 14 & 37,8 & 16 & 43,2 & 7 & 18,9 & 37 & 100 \\
\hline
\end{tabular}

Berdasarkan data pada tabel 7 diketahui bahwa Berdasarkan tabulasi silang diatas menunjukkan dari 15 responden yang menerapkan pola asuh demokratis lebih setengahnya kemandirian 
anak dalam kategori mandiri sebanyak 8 responden $(53,3 \%)$, dari 9 responden yang menerapkan pola asuh otoriter terdapat 1 anak $(11,1 \%)$ yang mandiri dan dari orang tua yang menerapkan pola asuh permisif lebih setengahnya anak tergolong mandiri sebanyak 7 resonden $(53,8 \%)$.

Hasil uji chi square diperoleh nilai $\rho$ $=0,023$ dan $\alpha=0,05$ sehingga $\rho<\alpha$ maka terdapat Hubungan Pola Asuh Orang Tua Dengan Tingkat Kemandirian Anak di TKIT Permata Mulia desa Banjaragung kec Puri Kab.Mojokerto.

\section{PEMBAHASAN}

Pola Asuh Orang Tua di TKIT Permata Mulia Desa Banjaragung Kecamatan Puri Kabupaten Mojokerto

Hasil penelitian yang dilakukan terhadap 37 responden di TKIT Permata Mulia desa Banjaragung kec puri Mojokerto, diperoleh data hampir setengahnya orang tua responden menerapkan pola asuh demokratis sebanyak 15 responden $(40,5 \%)$.

Pola asuh demokratis adalah pola asuh yang memprioritaskan kepentingan anak, akan tetapi tidak ragu-ragu mengendalikan mereka. Orang tua dengan pola asuh ini bersikap rasional, selalu mendasari tindakannya pada rasio atau pemikiran-pemikiran. Orang tua tipe ini juga bersikap realistis terhadap kemampuan anak, tidak berharap yang berlebihan yang melampaui kemampuan anak. Orang tua tipe ini juga memberikan kebebasan kepada anak untuk memilih dan melakukan suatu tindakan, dan pendekatannya kepada anak bersifat hangat (Junaidi, 2010). Pola asuh orang tua dapat dipengaruhi oleh faktor pendidikan, social ekonomi, kepribadian dan jumlah anak (Suparyanto, 2012).
Menurut peneliti pola asuh yang tepat untuk diterapkan pada orang tua yang mempunyai anak adalah pola asuh demokratis karena demokratisasi dan keterbukaan dalam suasana kehidupan keluarga adalah syarat esensial terjadinya pengakuan orang tua oleh anak dan dunia anak oleh orang tua dan situasi kehidupan yang hayati bersama. Pola asuh demokratis memang yang paling ideal untuk diterapkan baik pada semua anak maupun pada anak autis, tetapi mungkin adakalanya orang tua tidak menerapkan pola asuh ini dengan sepenuhnya, karena keterbatasan situasi dan kondisi. Anak juga perlu diberikan pola asuh yang permisif dan otoriter seperti halnya saat anak bermain kabel listrik baik diberikan pola asuh otoriter untuk keselamatan anak. Begitu juga perlu memberikan pola asuh permisif pada anak, jika anak sedang bermain yang tidak berbahaya atau tidak mengganggu, adakalanya orang tua memberikan pola asuh permisif.

Hasil penelitian ini menunjukkan bahwa 7 responden pada penelitian ini dapat menerapkan pengasuhan otoriter pada anak, hal ini ditunjukkan dengan cara mengasuh anak dengan aturan-aturan yang ketat seringkali memaksa anak untuk berperilaku seperti orang tuanya, kebebasan untuk bertindak atas nama dirinya sendiri dibatasi. Anak jarang diajak berkomunikasi dan bertukar pikiran dengan orang tua. Orang tua menganggap bahwa semua sikapnya sudah benar sehingga tidak perlu dipertimbangkan dengan anak. Disisi lain orang tua melarang anaknya melakukan sesuatu kegiatan meskipun kegiatan tersebut mungkin sangat disenangi atau diinginkan oleh sang anak, maka anak harus tetap rela untuk tidak melakukannya. 
Berdasarkan faktor usia ibu menunjukkan bahwa hampir seluruhnya responden berusia 20-35 tahun sebanyak 35 responden $(94,6 \%)$. Hasil tabulasi silang antara usia ibu dengan pola asuh anak menunjukkan dari 35 responden yang berusia 20-35 tahun terdapat 13 responden $(37,1 \%)$ yang menerapkan pola asuh demokratif.

Orang tua bukan hanya mampu mengkomunikasikan fakta, gagasan dan pengetahuan saja, melainkan membantu menumbuhkembangkan kepribadian anak. Pendapat tersebut merujuk pada teori Humanistik yang menitikberatkan pendidikan bertumpu pada peserta didik, artinya anak perlu mendapat perhatian dalam membangun sistem pendidikan. Apabila anak telah menunjukkan gejalagejala yang kurang baik, berarti mereka sudah tidak menunjukkan niat belajar yang sesungguhnya. Kalau gejala ini dibiarkan terus akan menjadi masalah di dalam mencapai keberhasilan belajarnya (Suparyanto, 2012).

Responden penelitian ini menunjukkan sebagian besar usia responden berusia 20-35 tahun sehingga mereka sudah mempunyai pengalaman yang cukup dalam melakukan perawatan pada anak terutama dalam memberikan pengasuhan yang tepat pada anak diusia 45 tahun.

Berdasarkan faktor pendidikan orang tua diperoleh data sebagian besar responden mempunyai latar belakang pendidikan SLTA sebanyak 23 responden $(62,2 \%)$. Berdasarkan tabulasi antara pendidikan ibu dengan pola asuh orang tua diperoleh data dari 28 responden yang lulusan SLTA sebagian besar pola asuhnya demokratis sebanyak 13 responden $(46,4 \%)$.
Pendidikan berarti bimbingan atau pertolongan yang diberikan dengan sengaja terhadap anak didik oleh orang dewasa agar ia menjadi dewasa. Latar belakang pendidikan orang tua dapat mempengaruhi pola pikir orang tua baik formal maupun non-formal kemudian juga berpengaruh pada aspirasi atau harapan orang tua kepada anaknya (Suparyanto, 2012). Menurut Suparyanto (2012) menyatakan Pendidikan berarti bimbingan atau pertolongan yang diberikan dengan sengaja terhadap anak didik oleh orang dewasa agar ia menjadi dewasa. Latar belakang pendidikan orang tua dapat mempengaruhi pola pikir orang tua baik formal maupun non-formal kemudian juga berpengaruh pada aspirasi atau harapan orang tua kepada anaknya.

Menurut peneliti hasil penelitian menunjukkan bahwa sebagian besar responden mempunyai latar belakang pendidikan SLTA atau menengah. Dengan latar belakang pendidikan menengah responden dapat menerapkan pola asuh yang cukup baik yang diperoleh berdasarkan informasi dan wawasan yang telah dimiliki, sehingga dengan pemahaman tersebut responden dapat menerapkan pola asuh yang baik seperti pola asuh demokratis. Tingkat pendididikan juga mempengaruhi pola asuh seseorang. Orang tua yang bersikap demokratis dan memiliki pandangan mengenai persamaan hak antara orang tua dan anak cenderung berkepribadian tinggi, dalam praktek pola asuhnya tampak sering membaca artikel ataupun mengikuti kemajuan mengenai perkembangan anak. Dengan pendidikan yang tinggi, pastinya mempunyai daya pikir yang tinggi dalam menerapkan pola asuh demokratis kepada anak. Hasil penelitian ini menunjukkan bahwa pendidikan seseorang 
mempengaruhi pola asuh yang dilakukan pada anaknya dimana hal ini terjadi karena pemahaman dari masing-masing orang tua tidak sama tentang bagaimana cara menerapkan pola asuh yang tepat untuk anak-anak mereka.

Berdasarkan hasil penelitian menunjukkan bahwa sebagian besar responden tidak bekerja atau sebagai ibu rumah tangga sebanyak 23 responden $(62,2 \%)$. Lingkungan sosial berkaitan dengan pola hubungan sosial atau pergaulan yang dibentuk oleh orang tua maupun anak dengan lingkungan sekitarnya. Anak yang sosial ekonaminya rendah cenderung tidak melanjutkan pendidikan ke jenjang yang lebih tinggi atau bahkan tidak pernah mengenal bangku pendidikan sama sekali karena terkendala oleh status ekonomi (Suparyanto, 2012). Menurut peneliti pekerjaan yang dimiliki oleh orang tua responden menunjukkan bahwa mereka lebih banyak tidak bekerja sehingga mereka mempunyai cukup waktu luang untuk meningkatkan informasi dan wawasan tentang penerapan pola asuh yang baik pada anak sehingga mereka dapat menerapkan wawasan yang dimiliki tersebut dalam merawat anak-anak mereka.

\section{Kemandirian Anak Usia Prasekolah}

Hasil penelitian tentang kemandirian anak menunjukkan hampir setengahnya anak prasekolah di TK Tunas Harapan mengalami kemandirian dalam kategori Mandiri sebanyak 16 responden $(43,2 \%)$.

Kemandirian merupakan salah satu aspek terpenting yang harus dimiliki setiap individu dan anak. Karena selain dapat mempengaruhi kinerjanya, juga berfungsi untuk membantu mencapai tujuan hidupnya, prestasi, kesuksesan serta memperoleh penghargaan. Tanpa didukung oleh sifat mandiri, maka individu maupun anak akan sulit untuk mencapai sesuatu secara maksimal dan akan sulit pula baginya untuk meraih kesuksesan (Yusuf, 2009).

Menurut penelitian ini sebagian besar anak responden termasuk dalam kategori mandiri. Hal ini terjadi karena orang tua memberikan stimulasi anak sehingga anak dapat melakukan aktivitas personal hygiene secara mandiri seperti orang tua memberikan contoh kepada anak bagaimana membersihkan rambut, memberikan contoh merawat dan menggunting kuku sehingga dengan pemberian pembelajaran tersebut anak dapat melakukan tindakan personal hygiene yang mudah dilakukan mereka sendiri secara mandiri seperti mandi, mencuci rambut.

\section{Hubungan Pola Asuh Orang Tua Dengan Tingkat Kemandirian Anak}

Hasil penelitian yang didapatkan bahwa terdapat hubungan pola asuh dengan kemandirian anak diperoleh nilai $\rho=0,023$ dan $\alpha=0,05$ sehingga $\rho<\alpha$. dan H1 diterima yang menunjukkan dari 15 responden yang menerapkan pola asuh demokratis sebagian besar kemandirian anak dalam kategori mandiri sebanyak 8 responden $(53,3 \%)$, dari 9 responden yang menerapkan pola asuh otoriter terdapat 3 anak $(33,3 \%)$ yang mandiri dan dari orang tuan yang menerapkan pola asuh permisif sebagian besar anak tergolong mandiri sebanyak 7 resonden $(53,8 \%)$.

Menurut David dalam Shochib (2010), keluarga dengan pola asuh demokratis dapat di jumpai pada keluarga seimbang yang ditandai oleh keharmonisan hubungan (relasi) antara ayah dan ibu, ayah 
dengan anak, serta ibu dengan anak. Orang tua bertanggung jawab dan dapat dipercaya, serta sebagai koordinator dan bersikap proaktif. Melalui teladan dan dorongan orang tua pula setiap masalah dihadapi dan diupayakan untuk dipecahkan bersama. Sedangkan kemandirian adalah diperoleh secara kumulatif selama perkembangan, dimana individu akan terus belajar untuk bersikap mandiri dalam menghadapi berbagai situasi lingkungan, sehingga individu pada akhirnya akan mampu berfikir dan bertindak sendiri dengan kemandiriannya (Tjandraningtyas, 2012). menurut Yusuf (2009) menyatakan Setiap orang tua mempunyai spesifikasi dalam mendidik. Ada orang tua yang mendidik anak secara otoriter, ada yang demokratis, dimana pendapat anak juga diterima oleh orang tua. Tetapi ada juga orang tua yang acuh dan masa bodoh dengan pendapat setiap anggota keluarga. Dari ketiga orang tua dalam mendidik kesemuanya membawa dampak pada kepribadian serta kemandirian anak.

Membebaskan anak memang membuat anak menjadi mudah melakukan suatu hal yang berguna untuk anaknya kelak, namun apabila tanpa adanya kontrol orangtua malah akan membuat anak menjadi sulit diatur. Orang tua yang permisif jarang melarang keinginan anak, memberikan kebebasan yang longgar pada anak, jarang menuntut dan menghukum anak, serta kurang menanamkan disiplin dan nilai-nilai yang patut atau tidak untuk dilakukan. Tidak ada pola asuh yang paling baik orang tua harus dapat memilih pola asuh yang tepat pada anak sesuai dengan situasi dan kondisi anak, yang diharapkan nantinya anak memiliki kemandirian yang baik sejak dini. Dengan kemandirian yang baik diharapkan anak dapat mengetahui tugas dan tanggung jawabnya.

\section{SIMPULAN}

Berdasarkan hasil penelitian didapatkan bahwa terdapat hubungan pola asuh dengan kemandirian anak diperoleh nilai $\rho=0,023$ dan $\alpha=0,05$ sehingga $\rho<$ $\alpha$. dan $\mathrm{H} 1$ diterima yang menunjukkan dari 15 responden yang menerapkan pola asuh demokratis sebagian besar kemandirian anak dalam kategori mandiri sebanyak 8 responden $(53,3 \%)$, dari 9 responden yang menerapkan pola asuh otoriter terdapat 3 anak $(33,3 \%)$ yang mandiri dan dari orang tuan yang menerapkan pola asuh permisif sebagian besar anak tergolong mandiri sebanyak 7 resonden $(53,8 \%)$.

\section{SARAN}

1. Orang tua lebih meningkatkan pengetahuan tentang perawatan pada anak seperti lebih banyak membaca buku, menonton televisi sehingga dengan pengetahuan yang lebih dapat menerapkan pengasuhan yang tepat pada anak.

2. Peneliti berikutnya dapat melakukan pengkajian yang lebih baik lagi seperti meneliti variabel lain yang mempengaruhi pola asuh, dan yang sehingga hasil penelitian dapat lebih optimal dan dapat mengembangkan ilmu pengetahuan terutama tentang pola asuh pada anak.

\section{DAFTAR PUSTAKA}

1. Ali, \& Asrori. (2004) Psikologi Remaja Perkembangan Peserta. Didik. Jakarta: PT. Bumi Aksara.

2. Arikunto. (2010). Prosedur Penelitian Pendekatan Suatu Praktek. Jakarta: Rineka Cipta. 
3. Bahara, Nasim. (2008). Kemandirian. Tersedia

http://www.nasheem.Blogsport.com/ 2008/04/ kemandirian.html. Diunduh 3 Desember 2016.

4. Depdiknas, (2005). Kamus Besar Bahasa Indonesia, Jakarta: Balai Pustaka.

5. Feby (2012). Hubungan Pola Asuh Orang Tua Dengan Kemandirian Anak. Jurnal Keperawatan Universitas Jember.

6. Habibi, M. (2007). Program Bimbingan Orang Tua Dalam Penerapan Pola Asuh Untuk Meningkatkan Kematangan Sosial Anak. Bandung: Universitas Pendidikan Indonesia.

7. Hidayat (2005). Pengantar Ilmu Keperawatan Anak. Jakarta : Salemba Medika.

8. Hidayat, (2007). Metode Penelitian Kebidanan dan Teknik Analisis Data. Jakarta : Penerbit Salemba Medika.

9. Jalaludin, (2003), Pengantar psikologi pendidikan, Bina Ilmu, Surabaya.

10. Judarwanto. (2005). Pemberian Nutrisi dan Asuhan Gizi Mempengarui Tumbuh Kembang Anak Secara Optimal. Jakarta: Gramedia Pustaka Utama.

11. Junaidi, Iskandar. (2006). The Power Of Soul For Great Health. Jakarta : Bhuana Ilmu Populer.

12. Kannisius. (2006). Membuat Prioritas,Melatih Anak Mandiri. Yogyakarta: Pustaka Media.

13. Kementerian Kesehatan RI. (2010). Profil Kesehatan Indonesia. Jakarta: Kementerian Kesehatan RI.

14. Kristiyanasari, (2010). Asuhan Keperawatan Neonatus dan Anak. Nuha Medika : Yogyakarta.
15. Lestari, Surti Deniarti. (2014). Pengaruh Pola Asuh Orang Tua Terhadap Kemandirian Anak Usia Dini (Usia 3-5 tahun) Studi Pada Keluarga di Kelurahan GunungPuyuh Kota Sukabumi. Skripsi. Universitas Pendidikan Indonesia.

16. Notoadmodjo. (2012). Metodologi Penelitian Kesehatan. Jakarta: Rineka Cipta.

17. Nouta (2007) Sampai di mana kemampuan anak prasekolah?, Jakarta : Klinik Pela.

18. Novita. (2007). Pengaruh Pola Asuh Orang Tua Terhadap Tingkat Kooperatif Anak Usia 3-5 Tahun Dalam Perawatan Gigi Dan Mulut. Jurnal Kesehatan Fakultas Kedokteran Gigi Universitas Hasanudin.

19. Nursalam. (2013). Konsep dan Penerapan Metodologi Penelitian Ilmu Keperawatan: Pedoman Skripsi, Tesis, dan Instrumen Penelitian Keperawatan. Edisi 1. Jakarta. Salemba Medika.

20. Nursalam. (2008). Konsep dan Penerapan Metodologi Penelitian Ilmu Keperawatan, Edisi 1. Jakarta : Salemba Medika.

21. Parker (2005). Menumbuhkan Dan Harga diri Anak. Jakarta : Pustaka Raya.

22. Petranto. (2006) Rasa Percaya Diri Anak adalah Pantulan Pola Asuh Orang Tuanya. Buletin Perkembangan anak.

23. Putri. (2013). Hubungan pola asuh orang tua terhadap kemandirian anak tk kelompok $b$ di tk dharma wanita persatuan i dan tk islam nurul muttaqin pesisir kec. Camplong. Jurnal Pendidikan Universitas Negeri Surabaya. 
24. Santrock. (2007). Perkembangan Anak. Jakarta : Erlangga.

25. Sarwono, Sarlito W. Meinarno,. (2013). Psikologi Sosial. Jakarta: Salemba Humanika.

26. Saryono (2010). Metodologi Penelitian Kesehatan. Yogyakarta : Nuha Medika.

27. Siswanto, Wahyudi, Lilik Nur Kholidah, Sri Umi Minarti. (2010). Membentuk Kecerdasan Spiritual Anak Pedoman Penting Bagi Orang Tua dalam Mendidik Anak. Jakarta: Amzah.

28. Setiadi (2007). Konsep Dan Penulisan Riset Keperawatan. Yogyakarta : Graha Ilmu.

29. Supartini. (2004). Buku Ajar Konsep Dasar Keperawatan Anak. Jakarta : EGC.

30. Suparyanto. (2012). Pola Asuh Orang Tua. Tersedia di http://www.suparyanto.web.ac.id diakses tanggal 15 November 2016.

31. Suseno (2014). Hubungan Antara Pola Asuh Orang Tua Dengan Kemandirian Anak Usia Pra-Sekolah Di Tk Aisyiyah Mendungan Sukoharjo. Jurnal Keperawatan Indonesia.

32. Tarwoto dan Wartonah. (2011). Kebutuhan Dasar ManusiaDan Proses Keperawatan Edisi 4. Jakarta : Salemba Medika.

33. Tati, Sugiyarti. (2005). Studi Kasus Pengelolaan Pusat Kegiatan Belajar Masyarakat (BPKM) Suaka dalam Meningkatkan Kemandirian Warga Belajar Keaksaraan Fungsional. Skripsi. Bandung: FIP Universitas Pendidikan Indonesia.

34. Theresia Indira. (2009). Pola Asuh Orang Tua. Artikel Ilmiah tersedia di http://www.tabloid nakita.com diakses tanggal 15 November 2016.
35. Wasis (2008). Pedoman Riset Praktis Untuk Profesi Perawat. Jakarta : EGC.

36. Wening. (2012). Bunda Sekolah Pertamaku. Solo : Tinta Medina.

37. Yusuf, Syamsu. (2009). Psikologi Perkembangan Anak Dan Remaja. Bandung: PT. Remaja Rosdakarya.

38. Yunanda. Febri (2012). Hubungan pola asuh orang tua dengan tingkat kemandirian personal hygiene ana usia prasekolah di desa balung lor kecamatan Balung kabupaten Jember. Jurnal Universitas Jember.

39. Zubaidah. 2014. Hubungan Pola Asuh Orang Tua Dengan Tingkatkemandirian Personal Hygiene Pada Anak Retardasi Mental Di SLB Negeri 2 Yogyakarta. Jurnal Keperawatan STIKES Aisyiyah Yogyakarta.

Cite This Article As: Vidya, H., Mustikasari, S. Hubungan Pola Asuh Orangtua Dengan Kemandirian Personal Hygiene Anak Usia Prasekolah Di TKIT Permata Mulia Desa Banjaragung Kecamatan Puri Kabupaten Mojokerto. Nurse and Health: Jurnal Keperawatan 2018; 7(1): 5160. 